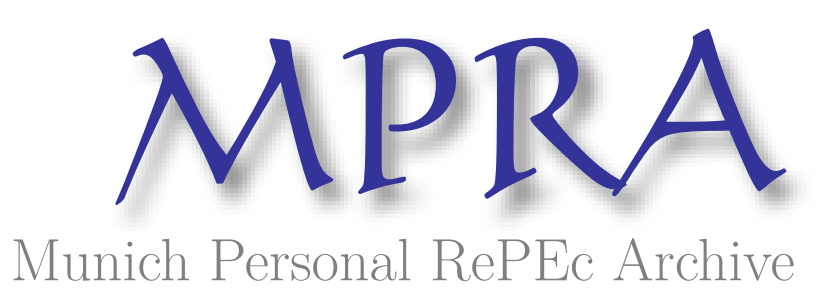

\title{
Government Debt and Economic Growth: Estimating the Debt Thresholds and Debt Intolerance
}

Swamy, Vighneswara

Institute of Economic Growth, Delhi

16 April 2015

Online at https://mpra.ub.uni-muenchen.de/63694/

MPRA Paper No. 63694, posted 19 Apr 2015 20:58 UTC 


\title{
Government Debt and Economic Growth: Estimating the Debt Thresholds and Debt Intolerance
}

\author{
Vighneswara Swamy \\ vs@iegindia.org
}

\begin{abstract}
The surge of Government debt during the post-global financial crisis and the ongoing euro zone sovereign debt crisis has begun raising concerns whether government debt levels have hit the tipping points. This study offers to contribute in the following ways: First, we find out whether the relationship between government debt and real GDP growth is weak for debt/GDP ratios below $90 \%$. Second, we estimate different thresholds for groups of economies based on their debt regimes, political economy structures and types of political governance, geographical considerations, and income levels. Third, we find out whether there is a declining negative effect beyond the debt threshold. Our results find the debt thresholds to vary in the range of 84 to 114 percent of GDP. We estimate that every additional 10 percent rise in debt-to-GDP ratio beyond the debt threshold costs 10 to 30 basis points of annual average real GDP growth. We find that different groups of countries experience debt threshold at different levels. Debt thresholds are dependent not necessarily on economic factors alone, but on other factors such as political economies and governance structures, geographies etc. Debt thresholds are sensitive to horizon of analysis.
\end{abstract}

Keywords: Government Debt, economic growth, debt thresholds, panel data, nonlinearity, country groupings

JEL Classification: C33, C36, E62, O5, O40, H63 


\section{Introduction}

In the backdrop of global financial crisis followed by the eurozone debt crisis, the advanced economies are at a crucial juncture as they face high debt levels. While some economists urge for more fiscal stimulus, others argue that raising debt levels would stunt economic growth and hence advocate austerity. Debt levels and debt thresholds have thus become central to the discussion of economic growth in advanced economies. A great deal of debate has been generated since the publication of Reinhart \& Rogoff's (RR) influential findings on the threshold effect of Government debt that a debt to GDP ratio of $90 \%$ or more could have a negative impact on growth. Their work drew pointed scrutiny from critics on endogeneity problems, existence of a common threshold and related issues. RR's findings have sparked a new literature seeking to assess whether their results were robust to allow for non-arbitrary debt brackets, control variables in a multivariate regression setup, reverse causality, and cross-country heterogeneity.

Growing empirical literature on government debt indicates a negative correlation between government debt and economic growth. This correlation becomes particularly strong when government debt approaches 100 percent of GDP (Reinhart and Rogoff 2010a; 2010b; Kumar and Woo 2010; Cecchetti et al. 2011). Cecchetti et al. (2011) use a sample of 18 OECD countries and derive a threshold for government debt at 85 percent of GDP. Reinhart and Rogoff (RR), in their influential articles, argue that higher levels of government debt are negatively correlated with economic growth, but that there is no link between debt and growth when government debt is below 90 percent of GDP (Reinhart and Rogoff, 2010a; Reinhart, Reinhart and Rogoff 2012). They deftly state that their results did not prove the existence of a causal relationship going from debt to growth. After the publication of the (critique) article by Herndon, Ash, and Pollin (2014) challenging some of RR's findings, the discussion on the relationship between debt and growth in advanced economies has become more animated. Krugman (2010), citing the case of Japan, argues that the link between debt and growth could be driven by the fact that it is low economic growth that leads to high levels of government debt.

In their much-debated study, RR demonstrate the threshold effect using the annual data on debt and growth for 20 advanced economies for the period 1946-2009. They split their sample based on country-years of public debt into four groups: (i) below 30 percent of GDP; (ii) between 30 to 60 percent of GDP; (iii) between 60 to 90 percent of GDP; and (iv) above 
90 percent of GDP. Thereafter, they estimate median and average GDP growth for each group to show that average and median GDP growth are significantly lower in the fourth group. They show that in the high debt group, median growth is approximately 1 percentage point lower and average growth is nearly 4 percentage points lower than that in other groups.

Some of the criticisms against RR's findings are that they suffer from econometric shortcomings. First, the findings are derived in the absence of supportive econometric tests for the relevance of the regimes. Second, the specification of exogenous thresholds in the debt-to-GDP ratio seems arbitrary in the absence of specific evidence to support the same. Third, the transitions around the debt thresholds appear to be abrupt. An important limitation is the failure to account adequately for heterogeneity in the effect of debt on growth that may arise due to alternative growth theories. There could be substantial cross-country heterogeneity in the debt-growth relationship though no evidence of systematic withincountry non-linearities (Eberhardt and Presbitero, 2013). Alternatively, why should we believe a priori that the effect of public debt on growth is confined only by excessive levels of debt? Further, why should the thresholds be not investigated endogenously employing appropriate econometric methods? We believe that nonlinear effects might be more complex and intricate to model than previously thought as they change over time, across countries and economic conditions.

We notice five inadequacies from the foregoing empirical debt-growth literature. First, none of the above-mentioned papers uses a dynamic panel threshold approach. Though we find Baum et al., (2013) employ dynamic panel threshold methodology to analyse the nonlinear impact of public debt on GDP growth, their study is confined to 12-euro area countries for the period 1990-2010. Second, none of the studies has focused on the different groupings of economies based on their political structures, income levels, regional geographies and debt regimes. Third, we do not find studies emphasising the need for establishing the presence of a causal link going from debt to growth and requires finding what economists call an 'instrumental variable'. Fourth, none of the papers offers a comprehensive analysis of the dynamics of Government debt and growth encompassing the use of dynamic panel threshold approach, verifying the correctness of debt thresholds, estimating the growth costs of debt intolerance beyond debt threshold. Fifth, there is a need to expand the horizon of the data sample as averaging across OECD / advanced countries alone would make such inferences difficult. 
This study seeks to put a dataset comparable to that of RR to a schematic econometric testing by first using similar debt regimes proposed by RR and then estimate the thresholds endogenously. We are interested to know are there different thresholds for different groups of economies based on their debt regimes, political economy structures, geographical considerations, and income levels. We seek to know whether the relationship between debt and growth is weak for debt levels below 90\% of GDP. Is there a declining negative relationship between debt and growth as the threshold levels are crossed? How critical would the impact of government debt be on growth beyond the threshold? What happens if the government debt stays above this threshold for an extended period?

Our study is unique as it overcomes the issues related to data adequacy, coverage of countries, heterogeneity, endogeneity, and non-linearities. We contribute to the current strand of literature on government debt and economic growth by extending the horizon of analysis to several country groupings and make the study inclusive of economic, political and regional diversities. More precisely, we find answers to: (i) whether the relationship between government debt and real GDP growth is weak for debt/GDP ratios below 90\%? (ii) Are there different thresholds for different groups of economies based on their debt regimes, political economy structures and types of political governance, geographical considerations, and income levels? (iii) Is there a declining negative relationship between debt and growth beyond the debt threshold? (iv) How critical would the impact of government debt be on growth beyond the threshold? and (v) What happens if the government debt stays above this threshold for an extended period of time? We provide a thorough econometric analysis of countries with large sample drawn from diverse groupings and allows for non-linearity estimation. Our data-intensive approach offers stylized facts, well beyond selective anecdotal evidence. We investigate the existence of an endogenously estimated threshold using a novel econometric technique that allows dealing properly with complex non-linearities on panel data. We validate our estimations by providing the evidence of debt intolerance for growth beyond the estimated threshold levels. This paper makes a distinct contribution to the debate by offering new empirical evidence based on a sizeable data set.

The paper is organised as follows. We present our data in section 2. In section 3 , we describe the estimation debt thresholds. We estimate the effects of debt intolerance in terms of growth costs of exceeding the debt threshold in Section 4. In section 5, we discuss the results and conclude in Section 6. 


\section{Data}

Our dataset comprises annual macroeconomic data on 252 countries, over the period 1960-2009. To maintain homogeneity in as much as it is for a large sample of countries over the course of five decades, we employ as a primarily source World Development Indicators (WDI) database 2014 of World Bank. We strengthen our data with the use of supplementary data sourced from International Monetary Fund, World Economic Outlook 2014 database, International Financial Statistics and data files, and Reinhart and Rogoff dataset on Debt-toGDP ratios.

In addition to our full sample, we arrange our data into five broad categories: (i) debt regimes, (ii) economy groupings, (iii) income groupings, (iv) political governance groupings, and (v) regional groupings. We place each of the 252 countries in the WDI list into its relevant category of our country groupings. However, each country's entry into the group is dependent on the data adequacy. Exclusion of any country of the WDI list from our sampling is solely due to data considerations (either non-availability or inadequacy of data). The list of countries covered in detail under different groupings and sub-groupings are provided in annexure 1 to 5 .

Debt regime based groupings

We group our sample countries into five debt regime groupings: 0-30\%, 31-60\%, 61$90 \%, 91-150 \%$, and $>151 \%$ comparable to RR groupings based on the average debt/GDP levels (Table 1).

Table 1: Sample description for debt regimes

Panel A: Sample frame for debt regime groupings

\begin{tabular}{|c|c|c|c|c|c|c|}
\hline Period & DR 0-30\% & DR 31-60\% & DR 61-90\% & DR 91 \& above & DR $151 \&$ above & Total \\
\hline 1960-2009 & 29 & 56 & 18 & 14 & 5 & 122 \\
\hline 1970-2009 & 32 & 52 & 20 & 14 & 4 & 122 \\
\hline $1980-2009$ & 24 & 53 & 24 & 16 & 5 & 122 \\
\hline 1990-2009 & 24 & 51 & 24 & 18 & 5 & 122 \\
\hline 2000-2009 & 24 & 45 & 20 & 13 & 5 & 107 \\
\hline \multicolumn{7}{|c|}{ Panel B: Government Debt and GDP Growth in debt regimes } \\
\hline \multirow{2}{*}{ Countries } & \multirow{2}{*}{ observations } & \multirow{2}{*}{ Debt Regime } & \multicolumn{2}{|c|}{ GDP Growth } & \multicolumn{2}{|c|}{ Government Debt } \\
\hline & & & Mean & Median & Mean & Median \\
\hline 8 & 160 & $0-30 \%$ & $5.06 \%$ & $4.83 \%$ & 27.15 & 27.79 \\
\hline 31 & 620 & $31-60 \%$ & $3.79 \%$ & $3.68 \%$ & 58.29 & 45.00 \\
\hline 20 & 400 & $61-90 \%$ & $2.71 \%$ & $2.70 \%$ & 80.08 & 82.87 \\
\hline 13 & 260 & $91-150 \%$ & $1.86 \%$ & $1.88 \%$ & 115.50 & 116.51 \\
\hline 4 & 80 & $>151 \%$ & $-1.08 \%$ & $-1.32 \%$ & 176.75 & 160.99 \\
\hline Total=76 & 1520 & & & & & \\
\hline
\end{tabular}




\section{Economy Groupings}

The World Economic Outlook April 2011 of IMF ${ }^{1}$ guides our classification of countries into advanced, emerging and developing. In addition, we consider two more broad groupings: BRICS (Brazil, Russia, India, China and South Africa) and OECD $^{2}$ (Organisation for Economic Co-operation and Development). Sample description for economy-based groupings is provided in Table 2.

Table 2: Sample description for economy groupings Panel A: Sample frame for economy groupings

\begin{tabular}{|c|c|c|c|c|c|c|}
\hline Period & Advanced & Emerging & OECD & BRICS & Developing & Total \\
\hline $1960-2009$ & 34 & 22 & 34 & 5 & 80 & 175 \\
\hline $1970-2009$ & 34 & 22 & 34 & 5 & 80 & 175 \\
\hline $1980-2009$ & 34 & 22 & 34 & 5 & 80 & 175 \\
\hline 1990-2009 & 34 & 22 & 34 & 5 & 80 & 175 \\
\hline 2000-2009 & 32 & 22 & 32 & 5 & 68 & 159 \\
\hline \multicolumn{7}{|c|}{ Panel B: Government Debt and GDP Growth in economy groupings } \\
\hline \multirow{2}{*}{ Countries } & \multirow{2}{*}{ observations } & \multirow{2}{*}{ Economies } & \multicolumn{2}{|c|}{ GDP Growth } & \multicolumn{2}{|c|}{ Government Debt } \\
\hline & & & Mean & Median & Mean & Median \\
\hline 32 & 640 & Advanced & $2.39 \%$ & $2.83 \%$ & 57.12 & 53.38 \\
\hline 5 & 100 & BRICS & $4.32 \%$ & $4.70 \%$ & 46.65 & 46.79 \\
\hline 57 & 1140 & Developing & $3.36 \%$ & $4.26 \%$ & 71.63 & 56.67 \\
\hline 21 & 420 & Emerging & $3.41 \%$ & $4.70 \%$ & 43.73 & 41.35 \\
\hline 33 & 660 & OECD & $2.64 \%$ & $2.90 \%$ & 55.17 & 51.61 \\
\hline Total $=148$ & 2960 & & & & & \\
\hline
\end{tabular}

\section{Income Groupings}

In arranging the data for income groupings, we follow the World Bank classification of economies ${ }^{3}$ updated for the fiscal year 2015. We consider high-income economies (HIC), heavily indebted poor countries (HPC), least developed countries (LDC), low-income economies (LIC), and middle-income economies (MIC). Table 3 provides the description of our sample based on income groupings.

\footnotetext{
${ }^{1}$ World Economic Outlook April 2011 of IMF (Table 4.1: Economy groupings) is available at http://www.imf.org/external/pubs/ft/weo/2011/01/pdf/text.pdf

${ }^{2}$ The details about OECD members are available at http://www.oecd.org/about/membersandpartners/list-oecd-membercountries.htm

${ }^{3}$ World Bank country classification is available at http://data.worldbank.org/about/country-and-lending-groups Accordingly, low income countries are those with gross national income (GNI) per capita of $\$ 1,045$ or less; middle income countries, $\$ 1,046-12,745$; high-income countries, $\$ 12,746$ or more. The least developed countries (LDC) are classified as per the criteria set by the United Nations Economic and Social Council.

Details available at http://www.un.org/en/development/desa/policy/wesp/wesp_current/2014wesp_country_classification.pdf Heavily indebted poor countries (HIPC) are classified according to the World Bank and IMF as part of their debt-relief initiative. These classifications are detailed in the World Economic Situation and Prospects (WESP) 2014 of the United Nations employed to delineate trends in various dimensions of the world economy. Also, refer Handbook on the Least Developed Country Category: Inclusion, Graduation and Special Support Measures (United Nations publication). Available from http://www.un.org/esa/analysis/devplan/cdppublications/2008cdphandbook.pdf
} 
Table 3: Sample description for income groupings

Panel A: Sample frame for income groupings

\begin{tabular}{|c|c|c|c|c|c|c|c|}
\hline Period & $\begin{array}{c}\text { Low-income } \\
\text { (LIC) }\end{array}$ & $\begin{array}{l}\text { Middle-income } \\
\text { (MIC) }\end{array}$ & $\begin{array}{l}\text { High-income } \\
\text { (HIC) }\end{array}$ & $\begin{array}{r}\text { Heavily indebt } \\
\text { poor (HPC) }\end{array}$ & Leas & $\begin{array}{l}\text { t developed } \\
\text { (LDC) }\end{array}$ & Total \\
\hline $1960-2009$ & 15 & 63 & 44 & 18 & & 17 & 220 \\
\hline 1970-2009 & 16 & 62 & 44 & 19 & & 18 & 221 \\
\hline 1980-2009 & 16 & 62 & 44 & 19 & & 18 & 221 \\
\hline 1990-2009 & 16 & 62 & 44 & 19 & & 18 & 221 \\
\hline 2000-2009 & 10 & 54 & 43 & 11 & & 9 & 181 \\
\hline \multicolumn{8}{|c|}{ Panel B. Government Debt and GDP Growth in Income groupings } \\
\hline \multirow{2}{*}{ Countries } & \multirow{2}{*}{ Observations } & \multirow{2}{*}{\multicolumn{2}{|c|}{ Economies }} & \multicolumn{4}{|c|}{ Government Debt } \\
\hline & & & & Mean & Median & Mean & Median \\
\hline 38 & 760 & \multicolumn{2}{|c|}{ High-income countries (HIC) } & $2.62 \%$ & $3.10 \%$ & 49.99 & 45.89 \\
\hline 16 & 320 & \multicolumn{2}{|c|}{$\begin{array}{l}\text { Heavily indebted poor countries } \\
\text { (HPC) }\end{array}$} & $3.12 \%$ & $3.95 \%$ & 124.10 & 103.87 \\
\hline 12 & 240 & \multicolumn{2}{|c|}{ Least developed countries (LDC) } & $3.76 \%$ & $4.78 \%$ & 100.86 & 81.39 \\
\hline 11 & 220 & \multicolumn{2}{|c|}{ Low-income countries (LIC) } & $2.92 \%$ & $4.17 \%$ & 91.37 & 87.06 \\
\hline 34 & 680 & \multicolumn{2}{|c|}{ Middle-income countries (MIC) } & $3.72 \%$ & $4.56 \%$ & 52.17 & 42.73 \\
\hline Total=111 & 2220 & & & & & & \\
\hline
\end{tabular}

Table 4: Sample description for political governance groupings

Panel A: Sample frame for political governance groupings

\begin{tabular}{|c|c|c|c|c|c|c|c|c|c|c|}
\hline Period & $\begin{array}{l}\text { Socialist or } \\
\text { Communist } \\
\text { Countries } \\
\text { (SC) }\end{array}$ & $\begin{array}{l}\text { Dictator } \\
\text { led } \\
\text { Countries } \\
\text { (DC) }\end{array}$ & $\begin{array}{l}\text { Coalition } \\
\text { Countries } \\
\text { (CC) }\end{array}$ & $\begin{array}{c}\text { Monarchy } \\
\text { Countries } \\
\text { (MC) }\end{array}$ & \multicolumn{2}{|c|}{$\begin{array}{l}\text { Islamic } \\
\text { Countries } \\
\text { (IC) }\end{array}$} & \multicolumn{2}{|c|}{$\begin{array}{l}\text { Parliamentary } \\
\text { Democracies } \\
\text { (PD) }\end{array}$} & $\begin{array}{c}\text { Federal } \\
\text { Democracies } \\
\text { (FD) }\end{array}$ & Total \\
\hline $1960-2009$ & 2 & 12 & 54 & 4 & \multicolumn{2}{|c|}{23} & \multicolumn{2}{|r|}{45} & 21 & 161 \\
\hline 1970-2009 & 2 & 12 & 54 & 4 & \multicolumn{2}{|c|}{23} & \multicolumn{2}{|r|}{45} & 21 & 161 \\
\hline 1980-2009 & 2 & 12 & 54 & 4 & \multicolumn{2}{|c|}{23} & \multicolumn{2}{|r|}{45} & 21 & 161 \\
\hline 1990-2009 & 2 & 12 & 54 & 4 & \multicolumn{2}{|c|}{23} & \multicolumn{2}{|r|}{45} & 21 & 161 \\
\hline 2000-2009 & 2 & 8 & 48 & 4 & \multicolumn{2}{|c|}{18} & \multicolumn{2}{|r|}{37} & 19 & 136 \\
\hline \multicolumn{11}{|c|}{ Panel B: Government Debt and GDP Growth in political governance groupings } \\
\hline \multirow{2}{*}{ Countries } & \multirow{2}{*}{ Observations } & \multirow{2}{*}{\multicolumn{3}{|c|}{ Countries }} & & \multicolumn{3}{|c|}{ GDP Growth } & \multicolumn{2}{|c|}{ Government Debt } \\
\hline & & & & & & $\mathrm{Me}$ & ean & Median & Mean & Median \\
\hline 31 & 620 & Coalitio & Countries & (CC) & & 3.1 & $0 \%$ & $3.24 \%$ & 66.24 & 61.59 \\
\hline 10 & 180 & Dictator & led Countri & es (DC) & & 3.8 & $5 \%$ & $4.45 \%$ & 87.63 & 69.63 \\
\hline 14 & 280 & Federal & Democracie & $S(F D)$ & & 3.1 & $1 \%$ & $3.36 \%$ & 54.26 & 54.83 \\
\hline 23 & 440 & Islamic & Countries (IC & & & 4.1 & $6 \%$ & $4.90 \%$ & 72.76 & 64.76 \\
\hline 4 & 80 & Monarc & רy Countries & $s(M C)$ & & 4.9 & $2 \%$ & $4.86 \%$ & 40.31 & 23.61 \\
\hline 16 & 320 & Parliam & ntary Demc & ocracies (PD & & 3.0 & $3 \%$ & $3.15 \%$ & 67.81 & 65.12 \\
\hline 2 & 40 & Socialist & /Communis & t Countries & (SC) & 6.3 & $2 \%$ & $5.75 \%$ & 36.44 & 18.74 \\
\hline Total=98 & 1960 & & & & & & & & & \\
\hline
\end{tabular}

Political governance groupings

We consider seven well acknowledged types of political governance systems; coalitiongovernments countries (CC), dictator-led countries $(D C)$, federal democracies (FD), Islamic countries (IC), monarchy countries (MC), parliamentary democracies (PD), and socialist/communist countries (SC). In doing so, we are guided by the World Fact book of 
$C I A^{4}$ and Encyclopedia Britannica. Table 4 provides the description of our sample based on political economy considerations.

\section{Regional groupings}

The fifth of our groupings is based on geographical considerations. We consider six broad classifications - Africa, Asia, Europe, North America, Oceania and South America. In doing so, we are guided by the publication of United Nations Statistics Division ${ }^{5}$. Table 5 provides the description of our sample based on regional groupings.

Table 5: Sample description for regional groupings

Panel A: Sample frame for regional groupings

\begin{tabular}{|c|c|c|c|c|c|c|c|c|c|}
\hline Period & Asia & \multicolumn{2}{|c|}{ South America } & \multicolumn{2}{|c|}{ North America } & Europe & Africa & Oceania & Total \\
\hline 1960-2009 & 25 & \multicolumn{2}{|c|}{16} & \multicolumn{2}{|c|}{10} & 39 & 27 & 5 & 122 \\
\hline 1970-2009 & 25 & \multicolumn{2}{|c|}{16} & \multicolumn{2}{|c|}{10} & 39 & 27 & 5 & 122 \\
\hline $1980-2009$ & 25 & \multicolumn{2}{|c|}{16} & \multicolumn{2}{|c|}{10} & 39 & 27 & 5 & 122 \\
\hline 1990-2009 & 25 & \multicolumn{2}{|c|}{16} & \multicolumn{2}{|c|}{10} & 39 & 27 & 5 & 122 \\
\hline 2000-2009 & 24 & \multicolumn{2}{|c|}{17} & \multicolumn{2}{|c|}{9} & 36 & 18 & 3 & 107 \\
\hline \multicolumn{10}{|c|}{ Panel B: Sample description for regional groupings } \\
\hline \multirow{2}{*}{ Countries } & \multirow{2}{*}{\multicolumn{2}{|c|}{ Observations }} & \multirow{2}{*}{\multicolumn{2}{|c|}{ Regions }} & \multicolumn{3}{|c|}{ GDP Growth } & \multicolumn{2}{|c|}{ Government Debt } \\
\hline & & & & & \multicolumn{2}{|c|}{ Mean } & Median & Mean & Median \\
\hline 21 & \multicolumn{2}{|c|}{420} & \multicolumn{2}{|l|}{ Africa } & \multicolumn{2}{|c|}{$3.35 \%$} & $3.92 \%$ & 91.94 & 80.08 \\
\hline 19 & \multicolumn{2}{|c|}{380} & \multicolumn{2}{|l|}{ Asia } & \multicolumn{2}{|c|}{$4.49 \%$} & $5.18 \%$ & 57.36 & 52.23 \\
\hline 34 & \multicolumn{2}{|c|}{680} & \multicolumn{2}{|c|}{ Europe } & 1.9 & & & 55.04 & 51.47 \\
\hline 7 & & 40 & North & merica & 3.5 & & & 57.45 & 54.85 \\
\hline 4 & & 0 & Oceani & & 2.9 & & & 42.39 & 43.87 \\
\hline 15 & & 00 & South $A$ & merica & 3.6 & & & 69.25 & 45.66 \\
\hline Total=100 & & 00 & & & & & & & \\
\hline
\end{tabular}

\section{Subsampling}

We explore the dimension of historical specificity by examining real GDP growth by government debt category for subsampled periods of the data: 1960-2009, 1970-2009, 19802009, 1990-2009, and 2000-2009. We do not extend our dataset beyond 2009, in view of the sudden and significant rise in government debt levels consequent to the government interventions in response to global financial

\footnotetext{
${ }^{4}$ The World Factbook of The Central Intelligence Agency of United States provides information on the history, people, government, economy, geography, communications, transportation, military, and transnational issues for 267 world entities. Available at https://www.cia.gov/library/publications/the-world-factbook/ Encyclopedia Britannica | political system. Details available at http://www.britannica.com/print/topic/467746

5 United Nations Statistics Division - Standard Country and Area Codes Classifications (M49). Details available at http://unstats.un.org/unsd/methods/m49/m49regin.htm
} 


\section{Variables}

We provide in Table 6 the description of variables and data sources.

Table 6: Description of variables and data sources

\begin{tabular}{|c|c|}
\hline Variable & Description \\
\hline $\begin{array}{l}\text { adr } \\
\text { Age dependency ratio (\% of } \\
\text { working-age population) }\end{array}$ & $\begin{array}{l}\text { Age dependency ratio is the ratio of dependents--people younger than } 15 \text { or } \\
\text { older than 64--to the working-age population--those ages 15-64. Data are } \\
\text { shown as the proportion of dependents per } 100 \text { working-age population. } \\
\text { Source: World Development Indicators (WDI) }\end{array}$ \\
\hline $\begin{array}{l}\text { fce } \\
\text { Final consumption } \\
\text { expenditure (\% of GDP) }\end{array}$ & $\begin{array}{l}\text { Final consumption expenditure is the sum of household final consumption } \\
\text { expenditure (private consumption) and general government final consumption } \\
\text { expenditure (general government consumption). Source: WDI }\end{array}$ \\
\hline $\begin{array}{l}\text { fdi } \\
\text { Foreign direct investment, } \\
\text { net inflows (\% of GDP) }\end{array}$ & $\begin{array}{l}\text { Foreign direct investments are the net inflows of investment to acquire a } \\
\text { lasting management interest ( } 10 \text { percent or more of voting stock) in an } \\
\text { enterprise operating in an economy other than that of the investor. } \\
\text { Source: WDI }\end{array}$ \\
\hline $\begin{array}{l}\text { gdpgr (GDPgrowth) } \\
\text { Real GDP growth (annual \%) }\end{array}$ & $\begin{array}{l}\text { Annual percentage growth rate of GDP at market prices based on constant } \\
\text { local currency. Source: WDI }\end{array}$ \\
\hline $\begin{array}{l}\text { gfc } \\
\text { General government final } \\
\text { consumption expenditure } \\
\text { (annual \% growth) }\end{array}$ & $\begin{array}{l}\text { Annual percentage growth of general government final consumption } \\
\text { expenditure based on constant local currency. Source: WDI }\end{array}$ \\
\hline $\begin{array}{l}\text { gfcf } \\
\text { Gross fixed capital formation } \\
\text { (annual \% growth) }\end{array}$ & $\begin{array}{l}\text { Average annual growth of gross fixed capital formation based on constant } \\
\text { local currency. Source: WDI }\end{array}$ \\
\hline $\begin{array}{l}\text { ggd (debt) } \\
\text { General government gross } \\
\text { debt }\end{array}$ & $\begin{array}{l}\text { Gross debt consists of all liabilities that require payment or payments of } \\
\text { interest and/or principal by the debtor to the creditor at a date or dates in the } \\
\text { future. This includes debt liabilities in the form of SDRs, currency and deposits, } \\
\text { debt securities, loans, insurance, pensions and standardized guarantee } \\
\text { schemes, and other accounts payable. } \\
\text { Source: World Economic Outlook (WEO) April 2012; Reinhart and Rogoff (RR) } \\
\text { data set }\end{array}$ \\
\hline $\begin{array}{l}\text { infl } \\
\text { Inflation (annual \%) }\end{array}$ & $\begin{array}{l}\text { Inflation as measured by the annual growth rate of the GDP implicit deflator } \\
\text { shows the rate of price change in the economy as a whole. Source: WDI }\end{array}$ \\
\hline $\begin{array}{l}\text { pg } \\
\text { Population growth (annual \%) }\end{array}$ & $\begin{array}{l}\text { Annual population growth rate for year } t \text { is the exponential rate of growth of } \\
\text { midyear population from year } t-1 \text { to } t \text {, expressed as a percentage. Source: WDI }\end{array}$ \\
\hline $\begin{array}{l}\text { rir } \\
\text { Real interest rate (\%) }\end{array}$ & $\begin{array}{l}\text { Real interest rate is the lending interest rate adjusted for inflation as } \\
\text { measured by the GDP deflator. } \\
\text { Source: WDI }\end{array}$ \\
\hline $\begin{array}{l}\operatorname{tgdp} \text { (openness) } \\
\text { Trade (\% of GDP) }\end{array}$ & $\begin{array}{l}\text { Trade is the sum of exports and imports of goods and services measured as a } \\
\text { share of gross domestic product. Source: WDI }\end{array}$ \\
\hline $\begin{array}{l}\text { ulf } \\
\text { Unemployed labour force }\end{array}$ & $\begin{array}{l}\text { Unemployment, total (\% of total labor force) (national estimate). } \\
\text { Unemployment refers to the share of the labor force that is without work but } \\
\text { available for and seeking employment. Definitions of labor force and } \\
\text { unemployment differ by country. Source: WDI }\end{array}$ \\
\hline
\end{tabular}

We present the dynamics of government debt and economic growth in different groupings of our sample in Figure 1 to 5. 
Figure 1: Government debt and growth in debt Regimes

This figure presents the dynamics of government debt and economic growth in debt regimes: 0-30; 31-60; 61-90; 91-150; 151 \% above for the period from $1960-2009$.
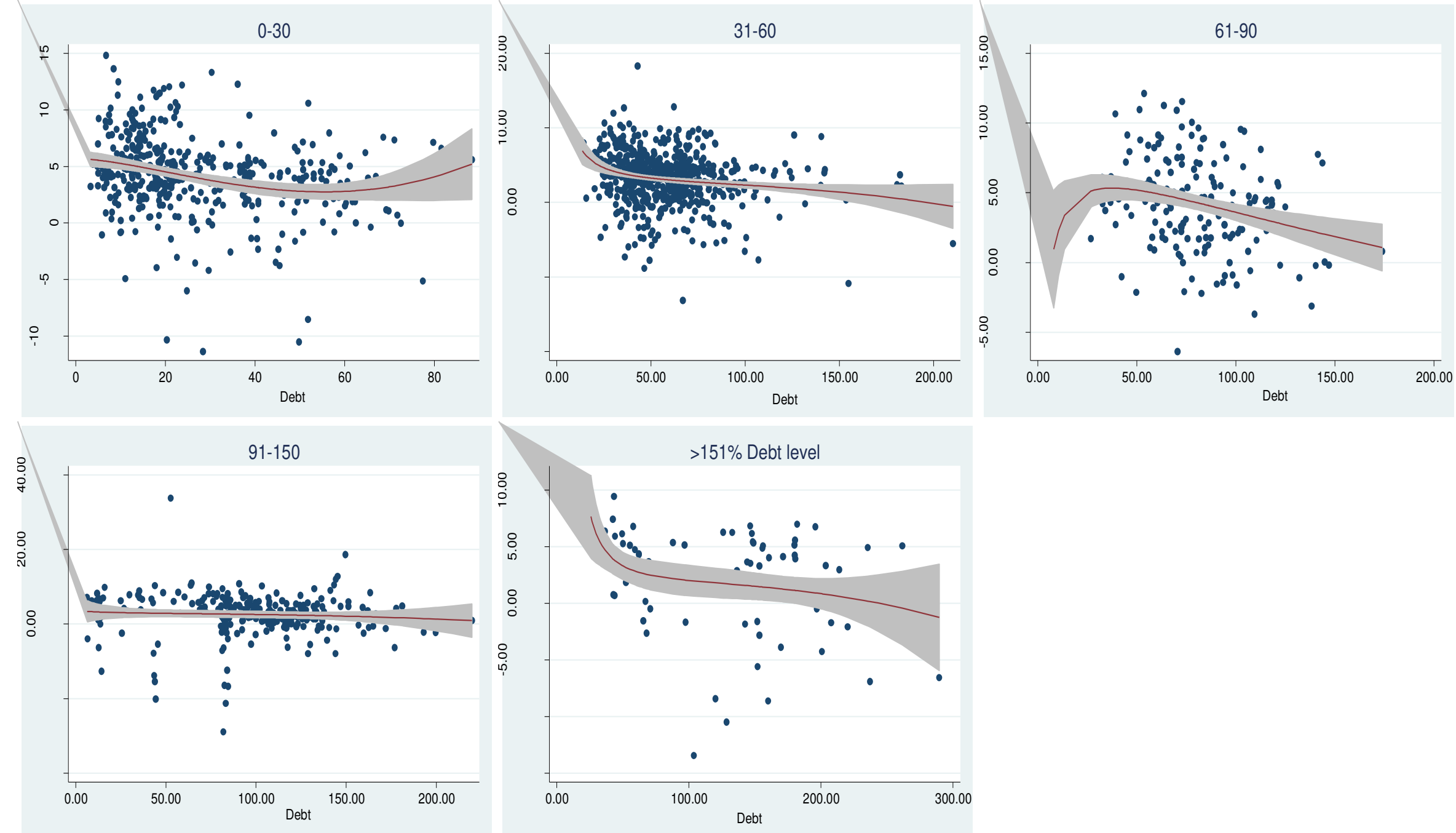
Figure 2: Government debt and growth in economy groupings

This figure presents the dynamics of government debt and economic growth in economy groupings: advanced countries, BRICS, developing countries, emerging countries, and OECD countries during the period 1960-2009.
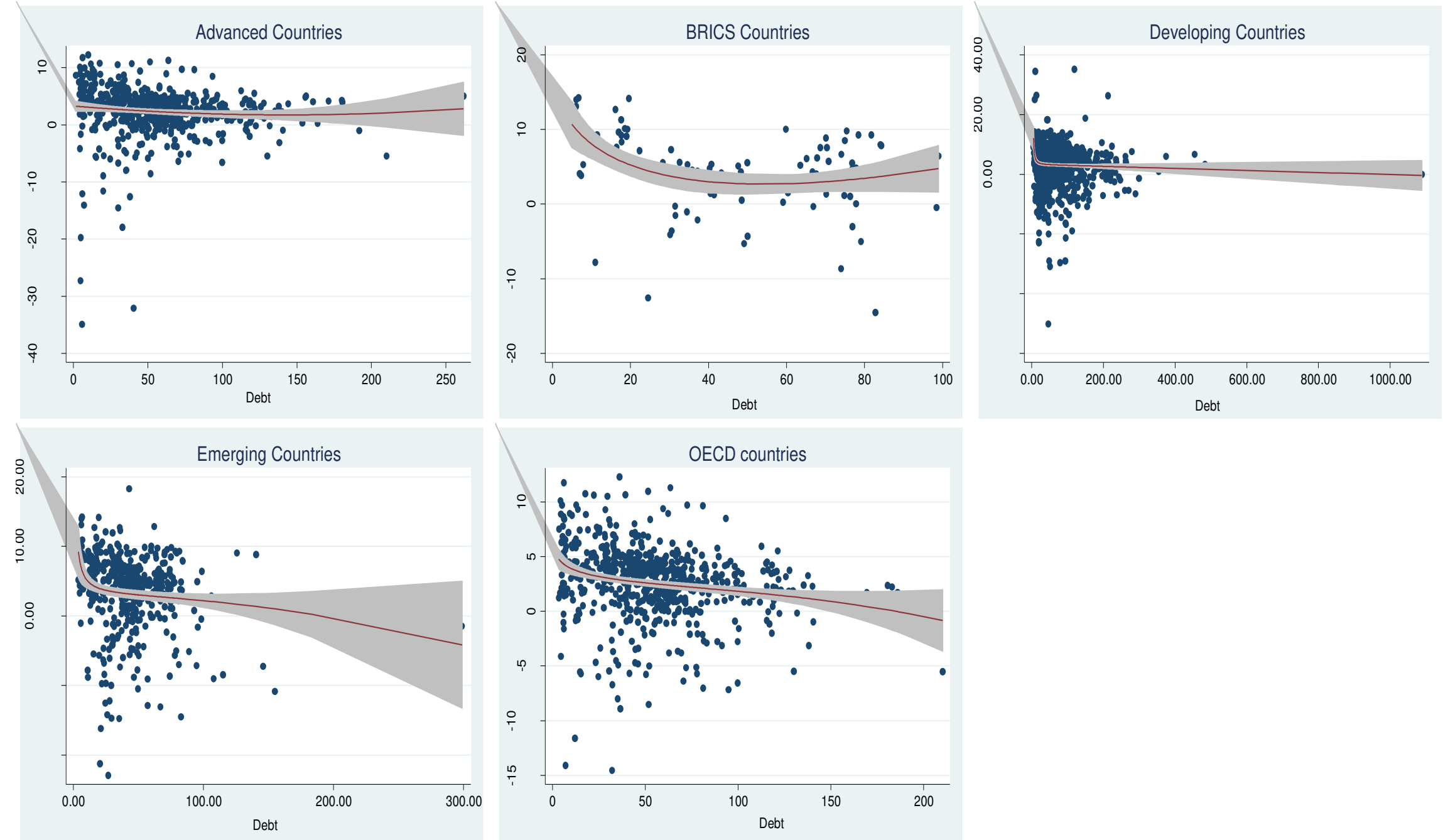
Figure 3: Government debt and growth in income groupings

This figure presents the dynamics of government debt and economic growth in income groupings: high-income countries (HIC), highly indebted poor countries (HPC), least developed countries (LDC), low-income countries (LIC), and middle-income countries (MIC) during the period $1960-2009$.
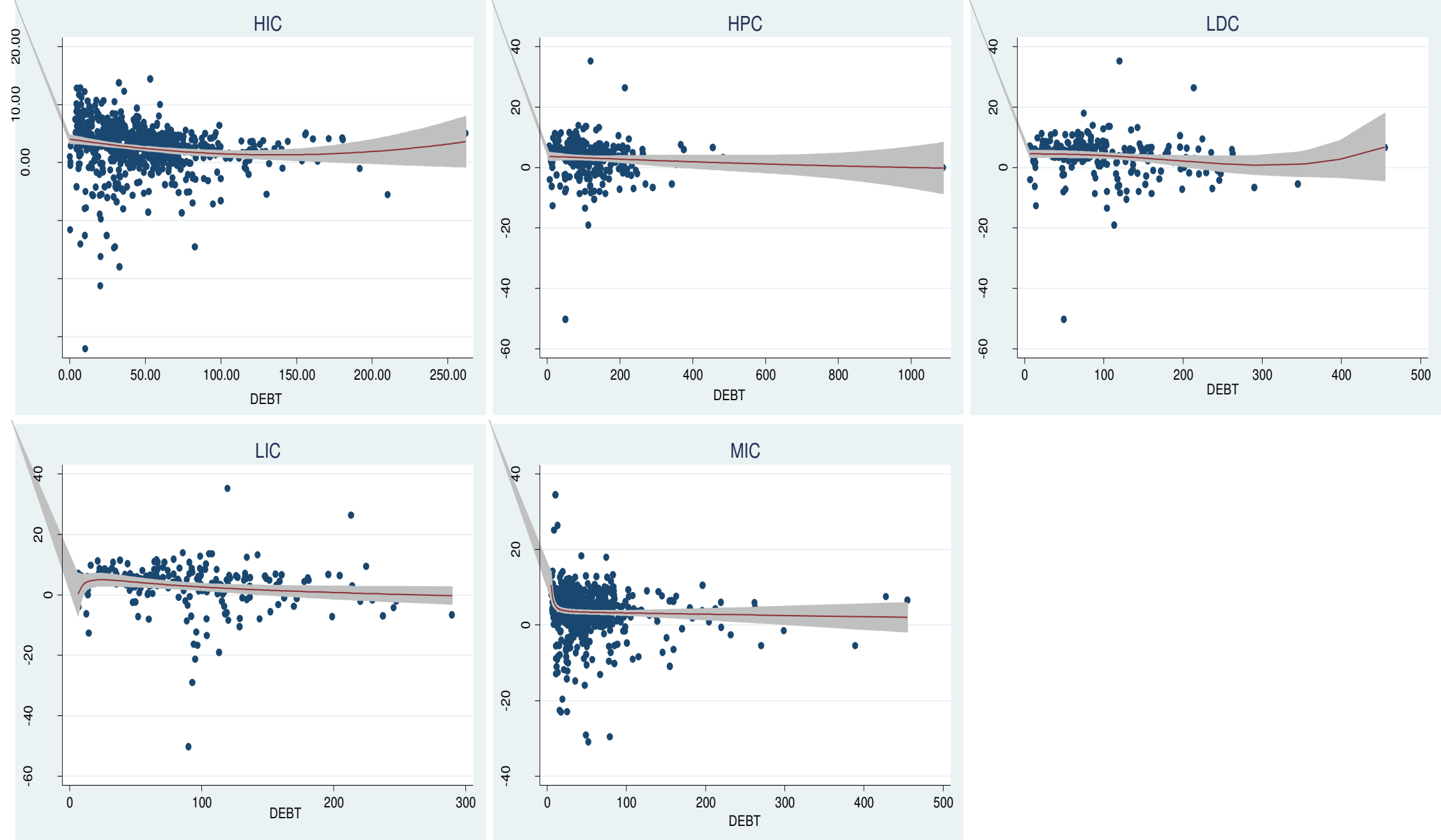
Figure 4: Government debt and growth in political governance groupings

This figure presents the dynamics of government debt and economic growth in political governance groupings: Islamic countries (IC); coalition countries (CC); dictator led countries (DC); federal democracies (FD); monarchy countries (MC); parliamentary democracies (PD); and socialist countries (SC) during the period 1960-2009.
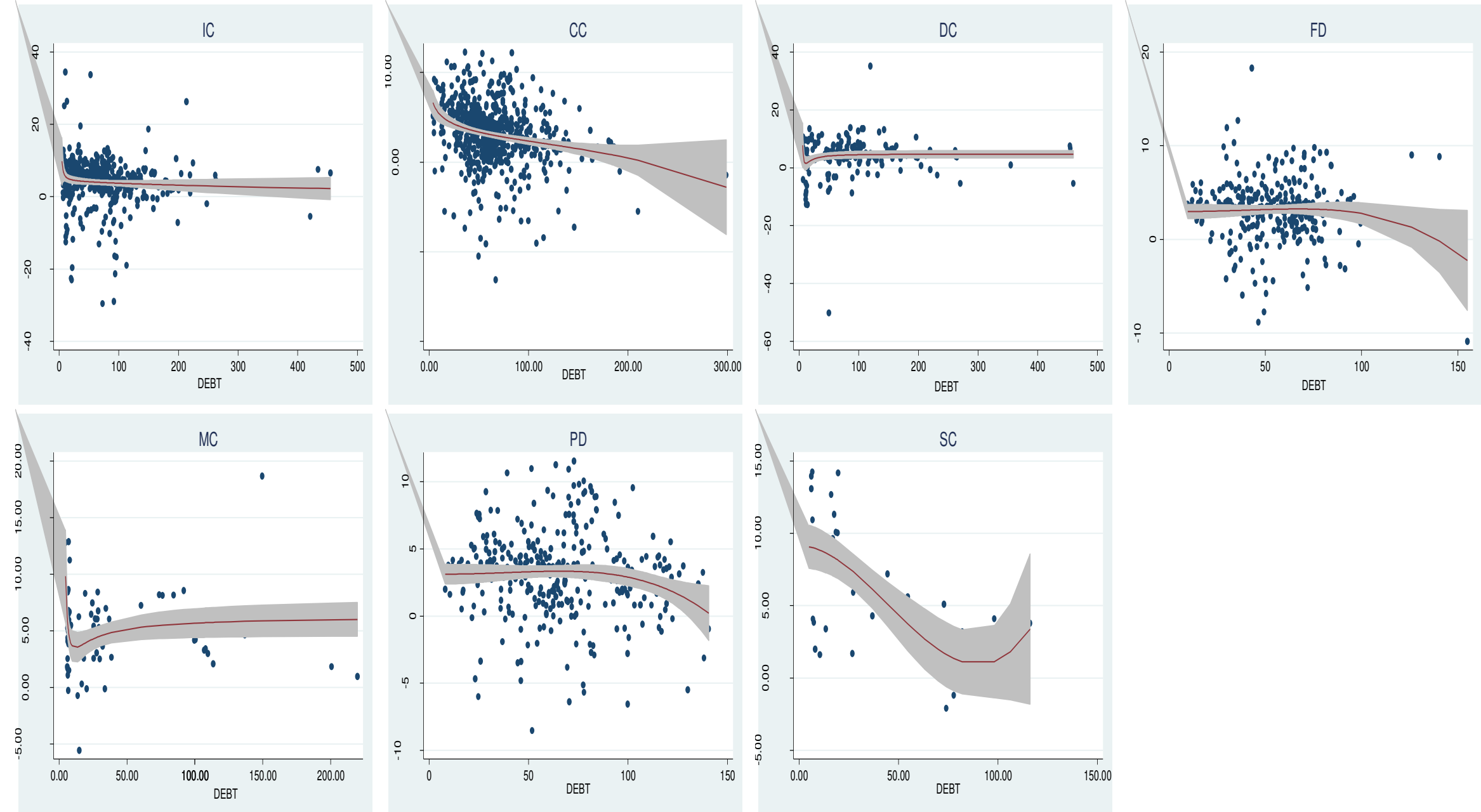
Figure 5: Government debt and growth in regional groupings

This figure presents the dynamics of government debt and economic growth in regional groupings: Africa, Asia, Europe, North America, Oceania, and South America during the period 1960-2009.
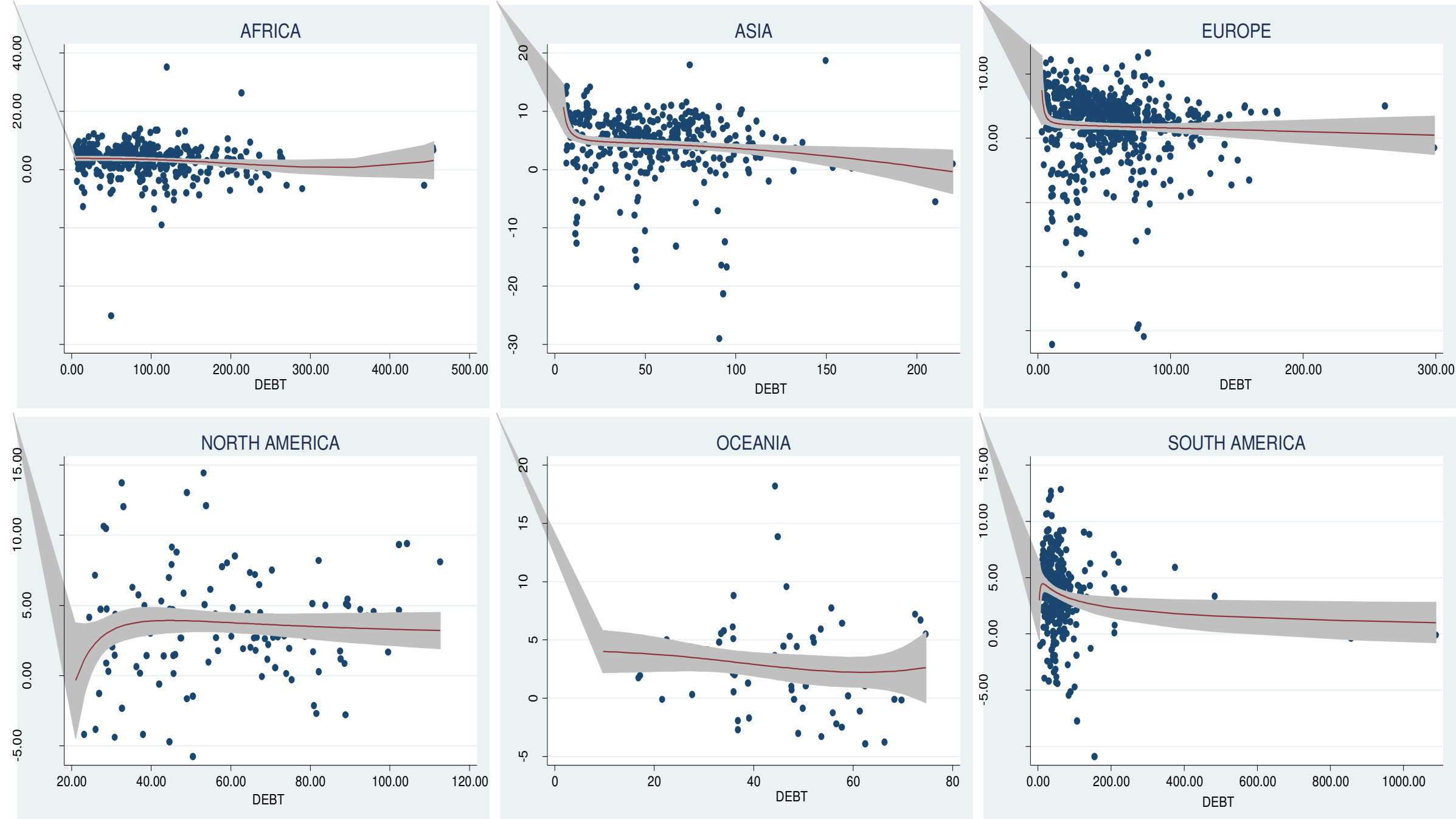


\section{Estimation of Debt Thresholds}

The theoretical literature on optimal debt level provides a rather unclear guidance. Different models, with different assumptions about household behavior, market completeness and time horizons, deliver different predictions about the optimal debt. The Barro-Ricardian literature almost stays silent on the issue of debt optimality. Keynesian view argues that rise in public debt can be welfare enhancing as it enhances both current and future consumption. The neoclassicals emphasize the positive effects of debt reduction particularly on investment. However, more literature that is recent contends for a broader role for government debt. It is desirable to research with large data sets to provide the empirical evidence on how debt levels shape economic growth.

Threshold models among the nonlinear regression models are attractive as they allow for regression that is a more flexible functional form of splitting data with certain unknown threshold values. Our modeling draws significant motivation from the threshold testing procedure proposed by Hansen (1999). Threshold regression models allow individual observations to be categorised based on the value of an observed variable. Hansen (1999) suggests that Least squares estimation of the threshold and regression slopes could be made using fixed-effects transformations and then Threshold regression methods could be developed for non-dynamic panels with individual specified fixed effects. Further, a nonstandard asymptotic theory of inference allows for construction of confidence intervals and testing of hypotheses. Panel threshold regression (PTR) model (Hansen, 1999, 2000) is superior to other models used to compute non-linear function and facilitate in estimating exogenous thresholds, rather than fixing them at arbitrary values.

The structural equation of interest is as below:

$$
\left.y_{t}^{j}=\hat{\beta}_{1}^{\wedge} x_{t}^{j} I\left(q_{t}^{j} \leq \gamma\right)+\beta_{2}^{\wedge} x_{t}^{j} I\left(q_{t}^{j}\right\rangle \gamma\right)+\mu_{j}+\varepsilon_{j t}
$$

where the data is from the balanced panel with $y_{t}^{j}, q_{t}^{j}, x_{t}^{j}: 1 \leq j \leq n, 1 \leq t \leq T$. The dependent variable $y_{t}^{j}$ is a scalar, the threshold variable $q_{t}^{j}$ is also a scalar and the regressor $x_{t}^{j}$ is a $k$ vector. $I(\cdot)$ is the indicator function. We assume, for each $t,\left(q_{t}^{j}, x_{t}^{j}, \varepsilon_{j t}\right)$ are 
independent and identically distributed (iid) across $j$ and are standard for fixed effect panel models with strictly exogenous regressors. $\beta_{1}^{\wedge}$ and $\beta_{2}^{\wedge}$ are the differing regression slopes distinguishing the regimes. The asymptotic analysis is with fixed T as $n \rightarrow \infty$. We now need to know whether the threshold effect is statistically significant. The null hypothesis of threshold effect is represented by the linear constraint $H_{0}=\hat{\beta_{1}}=\hat{\beta_{2}}$. The null of no threshold effect is not accepted if the p-value is lesser than the desired critical value. We set the indicator to use White-correction for heteroskedasticity. We employ sample trimming from the ends at $\mathrm{p}=0.15$ level; confidence interval at $95 \%$; and run a minimum of 5000 number of bootstraps to fine-tune the results in all the rounds of estimations for our different sample groupings.

Rewriting the Eqn. (1) in terms of our study variables:

$$
\text { GDPgrowth } \left.{ }_{t}^{j}=\hat{\beta_{1}} S_{t}^{j} I\left(\operatorname{Debt}_{t}^{j} \leq \gamma\right)+\hat{\beta_{2}} S_{t}^{j} I\left(\operatorname{Debt}_{t}^{j}\right\rangle \gamma\right)+\mu_{j}{ }^{+} \varepsilon_{j t}-- \text { Eqn. (2) }
$$

where $S_{j}$ is a vector of Solow regressors including $g f c f, g f c, t g d p, f c e, f d i$, infl, $p g$, and $a d r$. Debt is the threshold variable with GDP growth as the dependent variable. The above threshold regression specification with individual-specific effects is straightforward in estimating a fixed effects transformation. The asymptotic theory is believed to be nonstandard, but confidence intervals for the threshold are constructed by inverting the likelihood ratio statistic, as this construction is a natural by-product of the estimation method (Hansen, 1999).

We present the panel threshold regression estimations for all the groupings in our sample in Table 7 to 11 . The main result for the full sample for the period 1960-2009 is that the debt threshold is at 106.32 percent of GDP (see Table 7). We find debt thresholds for the periods $1970-2009$ at $105.03 \%, 1980-2009$ at $97.95 \%, 1990-2009$ at $114.81 \%$, and 20002009 at $84.19 \%$. These period-specific results suggest that the debt thresholds are not only country-specific but also time-variant. On an average, we find the debt thresholds to vary in the range of 84 to 114 percent of GDP for the full sample. 
Table 7: Panel threshold estimations for full sample

This table reports the estimated threshold levels of debt (as percent of GDP) with confidence intervals for different periods as described in Table 4. We also report the period of study sample, number of countries in the estimation panels, F-value, confidence interval at 95\%, sum of squared residuals (SSR), and estimated residual variance (ERV).

\begin{tabular}{ccccccc}
\hline Period & N & Threshold level & F-value & C.I at 95\% & \multicolumn{1}{c}{ SSR } & ERV \\
\hline Full Sample & & & & & & \\
[2000-2009] & 107 & 84.19 & 53.4611 & $013.3960-136.4260$ & 8954.77 & 9.2988 \\
{$[1990-2009]$} & 103 & 114.81 & 717.7543 & $113.5430-114.8510$ & 29485.93 & 15.066 \\
{$[1980-2009]$} & 67 & 97.95 & 172.5104 & $083.1188-099.8180$ & 16974.21 & 8.7361 \\
{$[1970-2009]$} & 67 & 105.03 & 784.3457 & $103.6898-106.1670$ & 27875.71 & 10.668 \\
{$[1960-2009]$} & 46 & 106.32 & 180.4392 & $095.0700-106.3200$ & 16953.92 & 7.5217 \\
\hline \hline
\end{tabular}

Our results for the full sample are comparable to the estimations of Reinhart and Rogoff (2010) who argue that growth slows down considerably as the government debt-toGDP ratio moves beyond $90 \%$. They rely on descriptive statistics of the advanced economies to show that debt has a detrimental effect on GDP growth as surpasses their estimated threshold.

A strand of recent empirical literature broadly seems to endorse the existence of a negative nonlinear effect of government debt on economic growth and the existence of threshold. Kumar and Woo (2010) establish the non-linear effects of debt on growth in their panel of 38 advanced and emerging countries for the period from 1970-2007. Using dummy variables for pre-determined ranges of debt they show that only very high (above 90 percent of GDP) levels have a significant negative impact. Caner et al. (2010) report the threshold level of the average long-run public debt to GDP at 77.1 percent for 79 countries for the period 1980-2010 (97.95 percent in our study for the comparable period). They also report a lower debt threshold at 64 percent of GDP for a subsample of 55 developing countries. Alternative to the use of a set of pre-determined debt to GDP brackets in comparing the growth, Minea and Parent (2012) employ panel smooth threshold regression (PSTR) model and find that debt has negative association with growth in the horizon of 90 to 115 percent. They also notice that the correlation turns positive as the debt surpasses the 115 percent level suggesting the existence of complex non-linearities that might not be captured by models that employed a set of exogenous thresholds. 


\section{Table 8: Panel threshold estimations for Political economy groupings}

This table reports the estimated threshold levels of debt (as percent of GDP) with confidence intervals for different political economy groupings as described in Table 4. The list of countries covered in this grouping is provided in Annexure 4. We also report the period of study sample, number of countries in the estimation panels, F-value, confidence interval at $95 \%$, sum of squared residuals (SSR), and estimated residual variance (ERV).

\begin{tabular}{lcccccc}
\hline Period & $\mathrm{N}$ & Threshold level & F-value & C.I at 95\% & SSR & ERV \\
\hline $\begin{array}{l}\text { 1. Coalition Countries } \\
{[1990-2009]}\end{array}$ & 31 & 84.30 & 50.5592 & $081.7640-099.8750$ & 2158.30 & 3.6644 \\
\hline $\begin{array}{l}\text { 2. Parliamentary Democracies } \\
{[1990-2009]}\end{array}$ & 16 & 87.49 & 28.0446 & $031.7430-094.4715$ & 816.05 & 2.6844 \\
\hline $\begin{array}{l}\text { 3. Islamic Countries } \\
{[1990-2009]}\end{array}$ & 22 & 84.90 & 83.4781 & $083.0410-097.0000$ & 7831.59 & 18.735 \\
\hline $\begin{array}{l}\text { 4. Dictator led Countries } \\
{[1980-2009]}\end{array}$ & 8 & 88.87 & 41.2033 & $060.0000-115.3300$ & 4326.29 & 18.647 \\
\hline $\begin{array}{l}\text { 5. Monarchy Countries } \\
{[1980-2009]}\end{array}$ & 4 & 21.39 & 40.7048 & $020.3820-090.9866$ & 1401.25 & 12.079 \\
\hline $\begin{array}{c}\text { 6. Federal Democracies } \\
{[1980-2009]}\end{array}$ & 14 & 40.73 & 72.8674 & $040.4662-042.5800$ & 1103.61 & 2.7183 \\
\hline $\begin{array}{l}\text { 7. Socialist/Communist Countries } \\
{[1990-2009]}\end{array}$ & 2 & 26.81 & 11.0893 & $007.4280-098.3760$ & 45.83 & 1.2062 \\
\hline
\end{tabular}

Coalition ruled countries are observed to experience debt threshold at 84.30 percent of GDP (see results in Table 8). This result is quite lower than the comparable period result of the full sample at 114 percent. Islamic countries are of special nature owing to their authoritarian adherence to Sharia law and other Islamic practices. These countries face their debt threshold at 84.90 percent of GDP. We study parliamentary democracies in view of their political economy dynamics and find the debt threshold at 87.49 percent of GDP. Federal democracies are of special interest of study in area of political economy. They are found to face their debt threshold at 40.73 percent of GDP. This threshold is substantially lower (almost by 57 percentage points) compared to the result of similar period analysis of the full sample. Kourtellos et al. (2013) show that public debt and economic growth are negatively correlated in countries with weak political institutions. Using a structural threshold regression model, they study the effects of government debt on the economic growth in a panel of 82 advanced and developing countries, and find strong evidence for threshold effects based on democracy, which implies that higher public debt results in lower growth for countries in the low-democracy regime.

Dictator led countries are of special interest in the study of political economy due to the whimsical and dictatorial policies of their ruling dictators. These countries face their debt 
threshold at 88.87 percent of GDP. This threshold is about 9 percentage points lower than that of comparable period result of the full sample (97.95\%). Monarchy countries are known for their allegiance to the ancient system of monarchic governance and their political economy is of special interest of study. The debt threshold of these countries is observed to be at 21.39 percent of GDP, which is significantly lower (almost by 76 percentage points) compared to that of the full sample. Finally, we study communist countries and find their debt threshold at 26.81 percent of GDP. This threshold is quite lesser compared to the result of the similar period of the full sample (almost lesser by 88 percentage points).

The difference between the threshold for the full sample and the threshold for other political economy groupings such as monarchy countries, federal democracies, and social/communist countries suggests that these countries encounter growth rate challenges at comparatively lower debt to GDP levels. Our findings imply that the relationship between public debt and growth is moderated by the quality of countries' political economies. More particularly, the governance structures, political philosophies, institutional arrangements affect the debt levels and growth strategies of the countries. When a country's political economy and governance strategies lead to higher public debt, growth tends to decline (else equal). On the other hand, if a country's political economy and governance mechanisms are of sufficiently high quality leading to lower public debt, its negative effect on growth is largely mitigated. Our findings therefore argue that the long run effects of debt on growth and the debt thresholds are influenced by the interplay of policy factors in the context of the political economy of the country.

\section{Table 9: Panel threshold estimations for Economy groupings}

This table reports the estimated threshold levels of debt (as percent of GDP) with confidence intervals for different economy groupings for the period 1990-2009 as described in Table 4. The list of countries covered in the economy groupings is provided in Annexure 2. We also report the period of study sample, number of countries in the estimation panels, F-value, confidence interval at $95 \%$, sum of squared residuals (SSR), and estimated residual variance (ERV).

\begin{tabular}{lcccccc}
\hline Economy groupings & $\mathrm{N}$ & Threshold level & F-value & C.I at 95\% & SSR & ERV \\
\hline 1. Advanced countries & & & & & & \\
2. BRICS countries & 27 & 67.05 & 24.3246 & $029.5360-094.4381$ & 1323.3420 & 2.5796 \\
& 5 & 31.47 & 26.3668 & $027.3560-040.7344$ & 250.1693 & 2.6334 \\
3. Developing countries & 57 & 84.17 & 106.9891 & $082.7982-084.5670$ & 21003.09 & 19.390 \\
4. Emerging economies & 21 & 24.69 & 31.0037 & $023.7850-025.0000$ & 3309.055 & 8.2934 \\
5. OECD countries & 33 & 36.03 & 74.7392 & $035.5620-035.6166$ & 2067.651 & 3.2977 \\
\hline
\end{tabular}


We notice highest debt threshold of 84.17 percent for developing countries and a lowest of 24.69 percent for emerging countries (see results in Table 9). For advanced countries, the debt threshold is found to be at 67.05 percent. We report the debt threshold 31.47 percent for BRICS group. For OECD group, we find the debt threshold at 36.03 percent. For a panel of 20 advanced OECD countries with 5-year averages for the period from 1946-2009, Egert (2015) estimates the debt threshold at 33.27 percent of GDP that is closer to our estimation.

For a mix of 30 advanced and emerging market economies for the period 1970-2007, Kumar and Woo (2010) report the debt threshold at 90 percent (67 percent in our study). We attribute the difference in the threshold estimations largely to the number and type of countries included in the study and the period of analysis. Caner et al., (2010) with the help of threshold least squares regression model based on a yearly data set of 79 developing and developed economies spanning a time period from 1980 to 2008 estimate a threshold of 77 percent public debt-to-GDP ratio.

\section{Table 10: Panel threshold estimations for Income groupings}

This table reports the estimated threshold levels of debt (as percent of GDP) with confidence intervals for different Income groupings for the period 1990-2009 as described in Table 4. The countries covered in the analysis are listed in Annexure 3. We also report the period of study sample, number of countries in the estimation panels, F-value, confidence interval at 95\%, sum of squared residuals (SSR), and estimated residual variance (ERV).

\begin{tabular}{|c|c|c|c|c|c|c|}
\hline Income Groupings & $\mathrm{N}$ & Threshold level & F-value & C.I at $95 \%$ & SSR & ERV \\
\hline \multicolumn{7}{|c|}{ 1. High Income Countries (HIC) } \\
\hline & 38 & 62.35 & 35.5162 & $032.6113-081.0559$ & 5005.597 & 06.9330 \\
\hline \multicolumn{7}{|c|}{ 2. Highly indebted Poor Countries (HPC) } \\
\hline & 16 & 132.03 & 58.1505 & $121.0580-160.5020$ & 4939.306 & 16.2477 \\
\hline \multicolumn{7}{|c|}{ 3. Least Developed Countries (LDC) } \\
\hline & 12 & 128.77 & 82.7686 & $120.3022-160.5020$ & 5018.676 & 22.0117 \\
\hline \multicolumn{7}{|c|}{ 4. Low Income Countries (LIC) } \\
\hline & 11 & 119.54 & 65.9034 & $094.0000-160.5020$ & 6056.577 & 28.9788 \\
\hline \multicolumn{7}{|c|}{ 5. Middle Income Countries (MIC) } \\
\hline & 34 & 23.56 & 92.6421 & $023.1932-023.7850$ & 9902.907 & 15.3296 \\
\hline
\end{tabular}

Our analysis for income groupings reveals that HPC countries have the highest debt threshold at 132.03 percent followed by LDC countries at 128.77 percent (see results in Table 10). The study reports debt thresholds for other groupings as below: LIC countries -119.54 percent, HIC countries - 62.35 percent and MIC countries - 23.56 percent. 
Table 11: Panel threshold estimations for Regional groupings

This table reports the estimated threshold levels of debt (as percent of GDP) with confidence intervals for different regional groupings for the period 1990-2009 as described in Table 4. The countries covered in the analysis are listed in Annexure 5. We also report the period of study sample, number of countries in the estimation panels, F-value, confidence interval at $95 \%$, sum of squared residuals (SSR), and estimated residual variance (ERV).

\begin{tabular}{llrrccc}
\hline \multicolumn{1}{c}{ Period } & N & Threshold level & F-value & C.I at 95\% & SSR & ERV \\
\hline 1. Africa & 21 & 144.85 & 131.2557 & $121.0000-160.5020$ & 6657.949 & 16.6866 \\
2. Asia & 19 & 45.61 & 31.9376 & $045.2970-111.4290$ & 3534.039 & 09.7896 \\
3. Europe & 34 & 78.19 & 102.6267 & $077.8340-079.0000$ & 6419.172 & 09.9368 \\
4. North America & 07 & 35.33 & 37.9909 & $032.6280-037.1741$ & 813.4135 & 06.1159 \\
5. Oceania & 04 & 55.92 & 40.949 & $053.6620-056.6070$ & 255.9509 & 03.3676 \\
6. South America & 15 & 84.17 & 28.2848 & $036.0396-142.9978$ & 1383.447 & 04.8542 \\
\hline
\end{tabular}

Regional groupings analysis reveals that Africa face their debt threshold at 144.85 percent followed by 35.33 percent for North America (see results in Table 11). Africa is followed by South America - 84.17, Europe - 78.19, Oceania - 55.92, and Asia - 45.61. Estimated thresholds in all country groupings are presented in Figure 6.

In a study of 12 euro-area countries over the period 1970-2008, estimations of Checherita-Westphal and Rother (2012) suggest that growth reaches a maximum when the debt-to-GDP ratio is around 90-100 percent (78 percent in our study of 34 European countries). For the same euro-area countries, using one year lagged debt ratios in a non-linear threshold panel model, Baum et al. (2013) report that impact of debt loses its significance beyond debt-to-GDP ratios of around $67 \%$. We attribute the differences in the threshold estimations to the factors associated with period of study, number of countries and the type of countries considered in these studies.

Our results offer adequate empirical evidence to the argument that if debt thresholds exist, there should be theoretical and empirical reasons why they might vary by country type. Debt may play out differently in different groups of countries depending on various factors such as efficiency of domestic financial markets; degree of openness (Frankel and Romer, 1999); and institutional structures and ease of access to financial markets (Alfaro and Vladim, 2008). Debt levels may also have implications for growth through the inflation channel. Empirical studies report interconnection between fiscal deficits and inflation in low-income countries but no systematic connection in high-income countries (Catao and Terrones, 2005). 
Figure 6: Debt Thresholds in Country Groupings
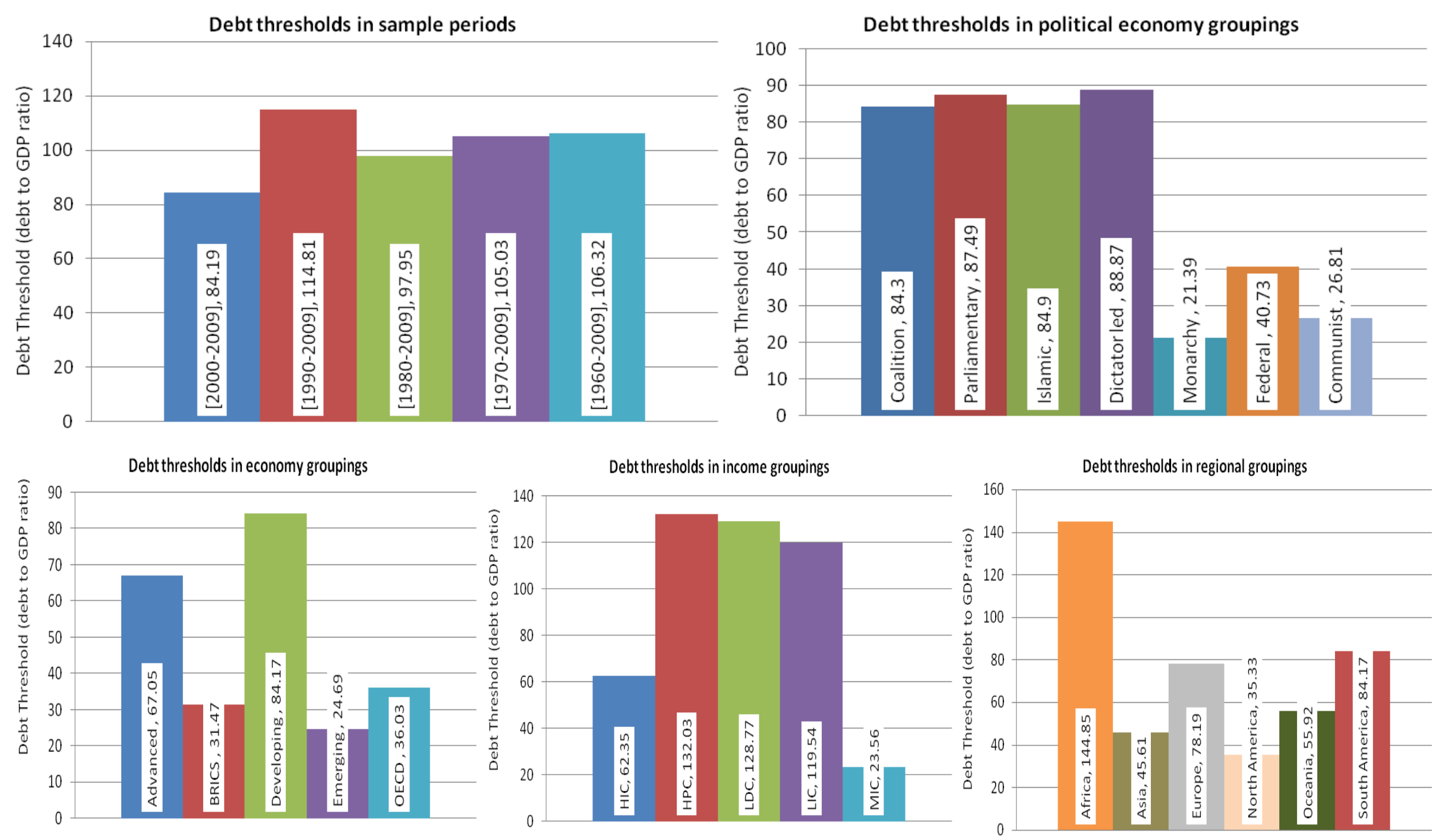
This analysis offers a cogent underpinning for the debt-growth relationship by formally testing for the existence of a threshold and estimating the threshold values for different groupings of countries while controlling for other important variables that influence growth. The key findings are that the threshold level of the average long-run public debt to GDP ratio on GDP growth is dependent on: (i) The horizon of the analysis, (ii) types of economies, (iii) types of geographies of the economies (iv) types of income levels of the countries, and (v) types of political governance structures. Though, the analysis of debt thresholds could be informative, but threshold levels needed to be interpreted with greater caution.

\section{Debt Intolerance and Growth Cost}

We extend our study to estimate the growth costs of exceeding the debt threshold. We do this by considering the debt threshold (114.81 percent rounded to 115 percent of GDP) estimated for our full sample of 103 countries (Table 4). We consider the econometric specifications provided in Eqn. (3) and Eqn. (4) to estimate the impact of debt on growth in debt regimes below and beyond the debt threshold.

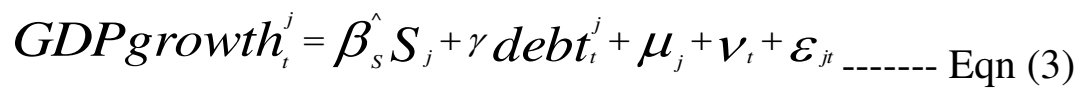

Where $S_{j}$ is a vector of Solow regressors including $g f c f, g f c$, tgdp, fce, fdi, infl, lagged GDP, $p g$, and $a d r$. It also includes the constant. $\mu_{j}$ is country-specific fixed effects; $v_{t}$ is time-fixed effects; $\varepsilon_{j t}$ is the unobservable error term.

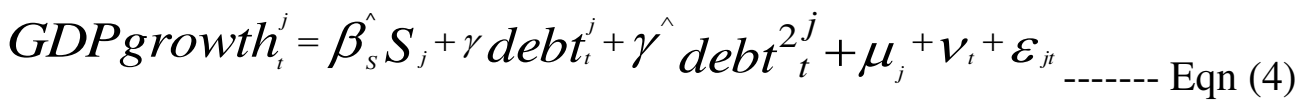

First, we estimate the debt-growth association both under linear and nonlinear models in the regime below the debt threshold of 115 percent of GDP and then in the same approach for the regime beyond the debt threshold.

\section{Robustness checks}

In order to ensure that the outliers do not influence the results, we identify the outliers by drawing the scatterplot of the partial correlation between debt and growth obtained with the IV regression and estimate the models by dropping them. We use the Huber-White 
sandwich correction to deal with the serially correlated residuals in the context of the presence of within-country time dependence and heteroscedacity of unknown form. An alternative approach of using the Newey and West estimator that allows modeling the autocorrelation process in the error term is also employed.

The method of PCSEs (suggested by Beck and Katz) is very robust when there is little or no correlation between unit effects and explanatory variables. It is argued that its performance declines as the correlation strengthens. We use the fixed effects estimator with robust standard errors that appears to do better in these situations (Kristensen and Wawro, 2003).

In addition, we test for the causality running from debt to growth employing Pairwise Demitrescu-Hurlin Panel Causality Tests. The results shown in Table 12 are significant and indicate causality running in both directions i.e. from debt to growth and growth to debt.

Table 12: Results of Pairwise Demitrescu-Hurlin Panel Causality Tests

\begin{tabular}{clccc}
\hline $\begin{array}{c}\text { Specifi- } \\
\text { cation }\end{array}$ & Null Hypothesis: & W-Stat. & $\begin{array}{c}\text { Zbar- } \\
\text { Stat. }\end{array}$ & Prob. \\
\hline \multirow{2}{*}{1} & GDP growth does not homogeneously cause debt & 4.6265 & 6.0140 & $2.00 \mathrm{E}-09$ \\
& Debt does not homogeneously cause GDP growth & 3.5252 & 3.0872 & 0.002 \\
\hline
\end{tabular}

We report the results of the econometric investigations in Table 13. We illustrate the debt-growth relationship for the regimes below and beyond the debt threshold $1115 \%$ of GDP) in Figure 7. 


\section{Table 13: Debt Threshold and its Growth Cost}

We report here the results of the estimations of growth costs as the debt exceeds the earlier estimated debt threshold (115 percent of GDP) in our study. We provide two analyses - one for below the debt threshold and the other for above the debt threshold. We run Panel Generalized Method of Moments regressions with appropriate instrument specifications. We employ 2SLS instrument weighting matrix with robust White period weights and use cross-section weights (PCSE) standard errors \& covariance. The mean (in the first row) and standard deviations (in the second row) of the variables are provided in columns (I-1) and (II: 1 ). We report the coefficients followed by standard errors in the parenthesis in columns (I-2), (I-3), (II-2) and (II: 3) for the Panel GMM regressions of both linear and non-linear models. We also report the goodness-offit indicators: R-squared values and Durbin-Watson Statistic.

\begin{tabular}{|c|c|c|c|c|c|c|}
\hline \multirow[b]{2}{*}{$\begin{array}{l}\text { Dependent variable: } \\
\text { GDP growth }\end{array}$} & \multicolumn{3}{|c|}{ I: (< debt threshold) } & \multicolumn{3}{|c|}{ II: (> debt threshold) } \\
\hline & $\begin{array}{l}\text { Mean/Std. } \\
\text { Dev } \\
(\mathrm{I}-1)\end{array}$ & $\begin{array}{l}\text { Linear } \\
\text { model } \\
\text { (PGMM) } \\
(\mathrm{I}-2)\end{array}$ & $\begin{array}{l}\text { Non linear } \\
\text { model } \\
\text { (PGMM) } \\
(\mathrm{I}-3)\end{array}$ & $\begin{array}{l}\text { Mean/Std. } \\
\text { Dev } \\
\text { (II-1) }\end{array}$ & $\begin{array}{l}\text { PGMM } \\
\text { results } \\
\text { (II-2) }\end{array}$ & $\begin{array}{l}\text { Non linear } \\
\text { model } \\
\text { (PGMM) } \\
(\text { II-3) }\end{array}$ \\
\hline Debt & $\begin{array}{l}46.223 \\
25.034\end{array}$ & $\begin{array}{l}0.0190 * * \\
(0.0082) \\
\end{array}$ & $\begin{array}{l}0.1282 * * * \\
(0.0399) \\
\end{array}$ & $\begin{array}{l}194.53 \\
151.36 \\
\end{array}$ & $\begin{array}{l}-0.0097^{* *} \\
(0.0037)\end{array}$ & $\begin{array}{l}-0.0286 \\
(0.0512) \\
\end{array}$ \\
\hline GDP growth (1-lag) & $\begin{array}{l}3.6479 \\
4.6654\end{array}$ & $\begin{array}{l}0.4209 * * * \\
(0.0420) \\
\end{array}$ & $\begin{array}{l}0.4220 * * * \\
(0.0430) \\
\end{array}$ & $\begin{array}{l}0.8692 \\
4.4367 \\
\end{array}$ & $\begin{array}{l}0.2811^{*} \\
(0.1572) \\
\end{array}$ & $\begin{array}{l}0.2198 \\
(0.1509) \\
\end{array}$ \\
\hline $\begin{array}{l}\text { Gross fixed capital } \\
\text { formation }\end{array}$ & $\begin{array}{l}4.6475 \\
15.551\end{array}$ & $\begin{array}{l}0.1165^{* * *} \\
(0.0121)\end{array}$ & $\begin{array}{l}0.1180^{* * *} \\
(0.0386) \\
\end{array}$ & $\begin{array}{l}8.5704 \\
16.627 \\
\end{array}$ & $\begin{array}{l}-0.0065 \\
(0.0347)\end{array}$ & $\begin{array}{l}-0.0204 \\
(0.0424)\end{array}$ \\
\hline $\begin{array}{l}\text { Government } \\
\text { expenditure }\end{array}$ & $\begin{array}{l}3.4805 \\
7.6312\end{array}$ & $\begin{array}{l}0.0569 * * * \\
(0.0217) \\
\end{array}$ & $\begin{array}{l}0.0572 \\
(0.0221) \\
\end{array}$ & $\begin{array}{l}-1.2602 \\
19.433 \\
\end{array}$ & $\begin{array}{l}-0.0588^{* *} \\
(0.0262)\end{array}$ & $\begin{array}{l}-0.0856^{* *} \\
(0.0396)\end{array}$ \\
\hline Trade Openness & $\begin{array}{l}81.845 \\
52.609\end{array}$ & $\begin{array}{l}0.0098 \\
(0.0102) \\
\end{array}$ & $\begin{array}{l}0.0142 \\
(0.0107) \\
\end{array}$ & $\begin{array}{l}70.651 \\
33.584 \\
\end{array}$ & $\begin{array}{l}0.0579 \\
(0.0553) \\
\end{array}$ & $\begin{array}{l}0.1033^{*} \\
(0.0581) \\
\end{array}$ \\
\hline $\begin{array}{l}\text { Foreign direct } \\
\text { investment }\end{array}$ & $\begin{array}{l}3.8375 \\
5.2044\end{array}$ & $\begin{array}{l}0.0410 \\
(0.0390)\end{array}$ & $\begin{array}{l}-0.0400 \\
(0.0386) \\
\end{array}$ & $\begin{array}{l}4.9828 \\
6.0896 \\
\end{array}$ & $\begin{array}{l}0.02811 \\
(0.0974) \\
\end{array}$ & $\begin{array}{l}-0.0220 \\
(0.0989)\end{array}$ \\
\hline Inflation & $\begin{array}{l}26.696 \\
146.34\end{array}$ & $\begin{array}{l}-0.0062^{* * *} \\
(0.0012) \\
\end{array}$ & $\begin{array}{l}-0.0066 * * * \\
(0.0012) \\
\end{array}$ & $\begin{array}{l}584.35 \\
3222.4 \\
\end{array}$ & $\begin{array}{l}4.26 \mathrm{E}-05 \\
(0.00014) \\
\end{array}$ & $\begin{array}{l}1.17 \mathrm{E}-04 \\
(0.00019) \\
\end{array}$ \\
\hline $\begin{array}{l}\text { Final consumption } \\
\text { expenditure }\end{array}$ & & & $\begin{array}{l}-0.0466 \\
(0.0323) \\
\end{array}$ & & & $\begin{array}{l}-0.1044 \\
(0.1195) \\
\end{array}$ \\
\hline Population growth & & & $\begin{array}{l}-0.1137 \\
(0.2033) \\
\end{array}$ & & & $\begin{array}{l}1.9566 \\
(0.7979) \\
\end{array}$ \\
\hline Debt-Squared & & & $\begin{array}{l}-0.0010 * * * \\
(0.0003)\end{array}$ & & & $\begin{array}{l}1.84 \mathrm{E}-05 \\
(4.65 \mathrm{E}-05)\end{array}$ \\
\hline Intercept & & $\begin{array}{l}-0.2086 \\
(0.9278)\end{array}$ & $\begin{array}{l}0.9031 \\
(2.8326) \\
\end{array}$ & & $\begin{array}{l}-1.4539 \\
(3.5532)\end{array}$ & $\begin{array}{l}4.4586 \\
(14.191) \\
\end{array}$ \\
\hline R-squared & & 0.6348 & 0.6216 & & 0.5411 & 0.5704 \\
\hline Durbin-Watson Stat & & 2.019 & 1.979 & & 2.031 & 2.05 \\
\hline
\end{tabular}

We find the degree of positive association of debt with growth in the debt regime below the debt threshold of 115 percent of GDP is econometrically significant in both the linear and non-linear specifications. The point estimates suggest that a 10-percentage point increase in the debt-to-GDP ratio is associated with 0.19 (in linear model) and 1.28 (in non-linear model) percent increase in average real GDP growth. Estimating the growth cost as the debt exceeds the estimated debt threshold in the debt regimes beyond the debt threshold, we find negative association of debt with growth. The point estimates indicate that a 10-percentage point increase in the debt-to-GDP ratio is associated with 0.097 (in linear model) and 0.286 (in 
non-linear model) percent reduction of annual average real GDP growth (Table 14). Alternatively, every additional 10 percent rise in debt-to-GDP ratio beyond the debt threshold costs 01 to 28 basis points of a percentage point of annual average real GDP growth.

Figure 7: Growth during below and beyond the debt threshold

The first part of the figure illustrates the growth relationship in the regimes below the debt threshold (115\% of GDP) and the second part presents the association in the regimes beyond the debt threshold.
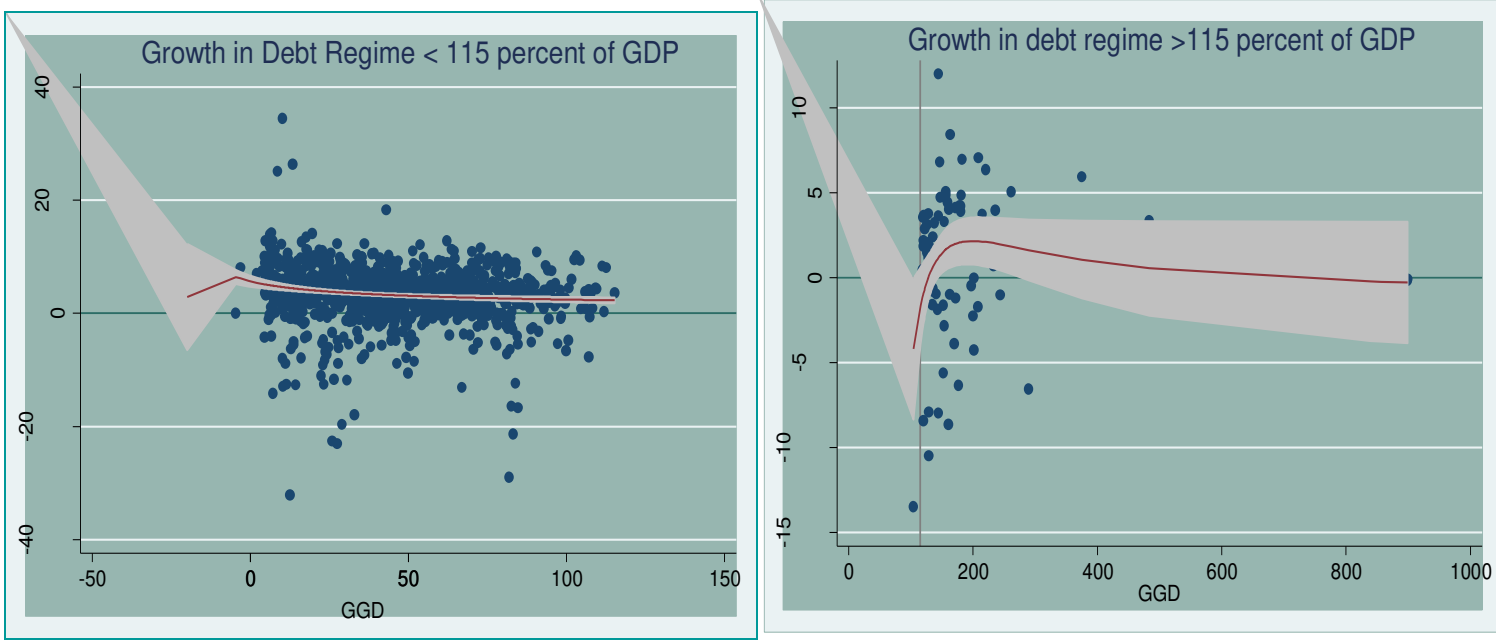

We notice that the average real GDP growth for countries with government debt beyond the debt threshold of 115 percent of GDP is 1.14 (median 1.89). For the countries with debt below the threshold, the average real GDP growth is noticed at 3.42 (median 3.79). On the other hand, Herndon, Ash, and Pollin (2014) challenging RR's findings for 20 advanced countries, observe that the average real GDP growth rate for countries carrying a public-debt-to-GDP ratio of over 90 percent is actually 2.2 percent, not -0.1 percent as published by RR

Some of the studies report comparable results. Caner et al., (2010) study 79 developing and developed economies spanning from 1980 to 2008 and observe that if debt is above their estimated threshold of 77 percent of GDP, each additional percentage point of debt costs 0.017 to 0.02 percentage points of annual real growth. In their study of 18 OECD countries, Cecchetti et al. (2011) show that 10 percentage points increase in the initial debt-to-GDP ratio is associated with a slowdown in annual real per capita GDP growth of approximately 20 basis points.

We have thus provided empirical evidence to the hypothesis that surpassing the debt threshold is costly for countries. Our analysis is based on long-term data, so that temporary 
deviations from the average need not have important negative effects on growth. In all likelihood, economic growth deteriorates if debt explosions push the debt ratios beyond the debt threshold and keep them there for decades.

\section{Summary and Conclusion}

The study finds the debt thresholds to vary in the range of 84 to 114 percent of GDP for the full sample for the different periods of analysis ranging from 10 to 50 years. The debt threshold estimations for political governance groupings reveal different thresholds: dictator led countries (88.87), parliamentary democracies (87.49), Islamic countries (84.90), coalition countries (84.30), federal democracies (40.73), socialist/communist countries (26.81), and monarchy countries (21.39).

Debt thresholds for different economy groupings are in the range of 24 to 84 percent. Developing economies experience the highest debt threshold at 84.17 percent of GDP, followed by advanced economies (67.05), OECD countries (36.03), BRICS (31.47) and emerging economies (24.69).

Income groupings of countries experience their debt threshold in the range of 24 to 132. Middle-income countries have the lowest debt threshold (24) and highly indebted poor countries have the highest debt threshold (132.03). On the other hand, high-income countries experience debt threshold at 62.35 while the low-income countries face their debt threshold at 119.54. Further, least developed countries experience debt threshold at 128.77. These results reveal that since low-income countries suffer from inadequate government revenues to fund their investment needs, their level of debt requirement stays higher compared to the middleincome countries that are found to generate reasonable level of government revenues to finance their investment needs.

Amongst the regional groupings, North America experiences lowest debt threshold (35.33) and Africa experiences the highest debt threshold (144.85). Africa is followed by South America (84.17), Europe (78.19), Oceania (55.92), and Asia (45.61).

The existence of debt threshold incited us to estimate the cost of exceeding it. We estimate the growth costs of exceeding the debt threshold by considering the debt threshold 115 percent of GDP estimated for the full sample. The point estimates indicate that every additional 10 percent rise in debt-to-GDP ratio beyond the debt threshold costs 10 to 30 basis points of annual average real GDP growth.

We have provided empirical evidence to the hypothesis that surpassing the debt threshold is costly for countries. Our analysis is based on long-term data, so that temporary 
deviations from the average need not have important negative effects on growth. Our conclusions made in the study, though based on econometric analysis, are open to questions and debate. We do not claim that the results are infallible, but do state that they are based on widely accepted econometric tools and based on sound economic logic. We opine that, in all likelihood, economic growth deteriorates if debt explosions push the debt ratios beyond the debt threshold and keep them there for decades.

\section{References:}

Baum Anja, Checherita Cristina-Westphal and Rother Philipp. (2013). Debt and growth: New evidence for the euro area. Journal of International Money and Finance 32: 809821

Checherita Cristina-Westphal and Rother Philipp. (2012). The impact of high government debt on economic growth and its channels: An empirical investigation for the euro area. European Economic Review 56: 1392-1405

Cecchetti Stephen, Madhusudan Mohanty and Fabrizio Zampolli. (2011). The real effects of debt. BIS Working Papers No. 352, Bank for International Settlements.

Egert Balazs. (2015). Public debt, economic growth and nonlinear effects: Myth or reality? Journal of Macroeconomics 43: 226-238

Hansen B E. (1999). Threshold effects in non-dynamic panels: estimation, testing and inference. Journal of Econometrics 93 (2): 345-368.

Herndon T, Ash M, Pollin R. (2014). Does high public debt consistently stifle economic growth? A critique of Reinhart and Rogoff. Cambridge Journal of Economics 38(2): 257-279.

Kourtellos A, Stengos T and Tan C M. (2013). The effect of public debt on growth in multiple regimes. Journal of Macroeconomics 38: 35-43.

Kristensen Ida Pagter and Wawro Gregory. (2003). Lagging the Dog? The Robustness of Panel Corrected Standard Errors in the Presence of Serial Correlation and Observation Specific Effects. Working Paper No. 54. Washington University in St. Louis. Extracted from http://polmeth.wustl.edu/mediaDetail.php?docId=54

Krugman, Paul (2010). "Reinhart and Rogoff Are Confusing Me." New York Times, 11 August.

Kumar Manmohan S and Jaejoon Woo. (2010). "Public Debt and Growth", IMF Working Papers, No. 10/174, International Monetary Fund

Minea Alexandru and Parent Antoine. (2012). Is High Public Debt Always Harmful to Economic Growth? Reinhart and Rogoff and Some Complex Nonlinearities. Working Paper No 201218, CERDI

Reinhart Carmen M and Kenneth S Rogoff. (2010a). "Debt and Growth Revisited", VoxEU.org, 11August.

Reinhart Carmen M and Kenneth Rogoff S. (2010b). Growth in a Time of Debt. American Economic Review: Papers and Proceedings 100(2): 573-578.

Reinhart Carmen M, Vincent R Reinhart and Kenneth S Rogoff (2012). Public debt overhangs: Advanced economy episodes since 1800. Journal of Economic Perspectives 26(3): 6986. 


\section{Appendices}

\begin{tabular}{|c|c|c|}
\hline \multicolumn{3}{|r|}{ Annexure 1: Countries covered in Debt Regime groupings } \\
\hline 1 & DR 0-30 (21) & $\begin{array}{l}\text { Azerbaijan, Bahrain, Botswana, Chile, China, Colombia, Congo, Rep., Czech } \\
\text { Republic, Estonia, Finland, Germany, Guatemala, Kazakhstan, Latvia, Namibia, } \\
\text { Norway, Oman, Paraguay, Romania, Slovenia, and Thailand. }\end{array}$ \\
\hline 2 & DR 31-60 (31) & $\begin{array}{l}\text { Argentina, Austria, Brazil, Canada, Denmark, Dominican Republic, Ecuador, } \\
\text { El Salvador, France, Ghana, Iceland, India, Indonesia, Japan, Kenya, Malaysia, } \\
\text { Mexico, Netherlands, New Zealand, Peru, Philippines, Portugal, South Africa, } \\
\text { Spain, Sweden, Tunisia, Turkey, United Kingdom, United States, Uruguay, and } \\
\text { Venezuela, RB. }\end{array}$ \\
\hline 3 & DR 61-90 (22) & $\begin{array}{l}\text { Algeria, Bolivia, Costa Rica, Cote d'Ivoire, Egypt, Arab Rep., Egypt, Arab Rep., } \\
\text { Greece, Ireland, Panama, and Singapore. }\end{array}$ \\
\hline 4 & DR $91-150(8)$ & $\begin{array}{l}\text { Belgium, Burundi, Central African Republic, Honduras, Italy, Jamaica, Jordan, } \\
\text { Kyrgyz Republic, Madagascar, Nigeria, Seychelles, Sri Lanka, and Tajikistan. }\end{array}$ \\
\hline 5 & DR 151 and above (5) & Congo, Dem. Rep., Cyprus, Malta, Nicaragua, and Zambia \\
\hline
\end{tabular}

\section{Annexure 2: Countries covered in Economy groupings}

Advanced Countries (27)

2 BRICS (5)
Developing Countries (57)

Australia, Austria, Belgium, Canada, Cyprus, Denmark, Finland, France, Germany, Greece, Hong Kong, Iceland, Ireland, Italy, Japan, Korea, Malta, Netherlands, New Zealand, Norway, Portugal, Slovenia, Spain, Sweden, Switzerland, United Kingdom, and United States.

Brazil, Russia, India, China, and South Africa

Albania, Argentina, Azerbaijan, Bahamas, Belize, Bolivia, Bulgaria, Burundi, Cameroon, China, Colombia, Congo, Congo Rep, Costa Rica, Cote d'Ivoire, Dominican Republic, Ecuador, Egypt, Guatemala, Honduras, India, Indonesia, Jordan, Kazakhstan, Kenya, Kyrgyz Republic, Lesotho, Madagascar, Malaysia, Mauritius, Mexico, Moldova, Morocco, Namibia, Nicaragua, Pakistan, Panama, Papua New Guinea, Paraguay, Peru, Philippines, Romania, Russian Federation, Rwanda, Sierra Leone, South Africa, Sri Lanka, Sudan, Tajikistan, Thailand, Trinidad and Tobago, Tunisia, Uganda, Ukraine, Uruguay, Venezuela, and Zambia

4 Emerging economies Argentina, Brazil, Bulgaria, Chile, China, Colombia, India, Indonesia, Lithuania, (21) Malaysia, Mexico, Peru, Philippines, Poland, Romania, Russian Federation, South Africa, Thailand, Turkey, Ukraine, and Venezuela.

Algeria, Australia, Austria, Belgium, Canada, Chile, Czech Republic, Denmark, Estonia, Finland, France, Germany, Greece, Iceland, Ireland, Italy, Japan, Korea,

$5 \quad$ OECD Countries (33) Luxembourg, Mexico, Netherlands, New Zealand, Norway, Poland, Portugal, Slovak Republic, Slovenia, Spain, Sweden, Switzerland, Turkey, United Kingdom, and United States. 


\begin{tabular}{|c|c|c|}
\hline \multicolumn{3}{|r|}{ Annexure 3: Countries covered in Income groupings } \\
\hline 1 & $\begin{array}{l}\text { High Income Countries } \\
\text { HIC (38) }\end{array}$ & $\begin{array}{l}\text { Australia, Austria, Bahamas, Bahrain, Belgium, Canada, Chile, Cyprus, Czech } \\
\text { Republic, Denmark, Estonia, Finland, France, Germany, Hong Kong SAR, } \\
\text { China, Iceland, Italy, Japan, Korea, Latvia, Lithuania, Luxembourg, Malta, } \\
\text { Netherlands, New Zealand, Norway, Oman, Poland, Portugal, Russian } \\
\text { Federation, Slovak Republic, Slovenia, Spain, Sweden, Switzerland, Trinidad } \\
\text { and Tobago, United Kingdom, United States }\end{array}$ \\
\hline 2 & $\begin{array}{l}\text { Highly indebted Poor } \\
\text { Countries } H P C(16)\end{array}$ & $\begin{array}{l}\text { Bolivia, Burundi, Cameroon, Congo DR, Congo R, Cote d'Ivoire, Ethiopia, } \\
\text { Gambia, Honduras, Madagascar, Nicaragua, Rwanda, Sierra Leone, Sudan, } \\
\text { Uganda, and Zambia. }\end{array}$ \\
\hline 3 & $\begin{array}{l}\text { Least Developed } \\
\text { Countries } L D C(12)\end{array}$ & $\begin{array}{l}\text { Bhutan, Burundi, Congo DR, Ethiopia, Lesotho, Madagascar, Nepal, Rwanda, } \\
\text { Sierra Leone, Sudan, Uganda, and Zambia }\end{array}$ \\
\hline 4 & $\begin{array}{l}\text { Low Income Countries } \\
\text { LIC (11) }\end{array}$ & $\begin{array}{l}\text { Burundi, Congo DR, Ethiopia, Gambia, Kenya, Madagascar, Nepal, Rwanda, } \\
\text { Sierra Leone, Tajikistan, and Uganda }\end{array}$ \\
\hline 5 & $\begin{array}{l}\text { Middle Income } \\
\text { Countries (34) }\end{array}$ & $\begin{array}{l}\text { Albania, Argentina, Azerbaijan, Belize, Bhutan, Botswana, Brazil, Bulgaria, } \\
\text { China, Colombia, Congo R, Dominican Republic, Ecuador, El Salvador, } \\
\text { Guatemala, India, Indonesia, Kazakhstan, Malaysia, Mauritius, } \\
\text { Mexico, Moldova, Namibia, Paraguay, Peru, Philippines, Romania, South } \\
\text { Africa, Sudan, Thailand, Tunisia, Turkey, Ukraine, and Venezuela }\end{array}$ \\
\hline
\end{tabular}

Annexure 4: Countries covered in Political economy groupings

\begin{tabular}{|c|c|c|}
\hline 1 & Coalition Countries (31) & $\begin{array}{l}\text { Austria, Belgium, Brazil, Bulgaria, Chile, Denmark, Dominican Republic, } \\
\text { Finland, France, Germany, Greece, Iceland, India, Indonesia, Ireland, Italy, } \\
\text { Japan, Kenya, Malaysia, Morocco, Netherlands, New Zealand, Norway, } \\
\text { Pakistan, Panama, Portugal, Sri Lanka, Sweden, Switzerland, Thailand, and } \\
\text { United Kingdom. }\end{array}$ \\
\hline 2 & $\begin{array}{l}\text { Parliamentary } \\
\text { Democracies (16) }\end{array}$ & $\begin{array}{l}\text { Algeria, Australia, Austria, Belgium, Canada, Finland, Germany, Greece, } \\
\text { Iceland, India, Ireland, Italy, New Zealand, Portugal, Singapore, and Turkey. }\end{array}$ \\
\hline 3 & Islamic Countries (22) & $\begin{array}{l}\text { Albania, Azerbaijan, Bahrain, Bangladesh, Cameroon, Cote d'Ivoire, Egypt, } \\
\text { Gambia, Indonesia, Jordan, Kazakhstan, Malaysia, Morocco, Nigeria, Oman, } \\
\text { Pakistan, Sierra Leone, Sudan, Tajikistan, Tunisia, Turkey, and Uganda. }\end{array}$ \\
\hline 4 & Dictator led Countries (8) & $\begin{array}{l}\text { Congo, Egypt, Ethiopia, Madagascar, Rwanda, Sudan, Tunisia, and } \\
\text { Zimbabwe. }\end{array}$ \\
\hline 5 & Monarchy Countries (4) & Bahrain, Jordan, Luxembourg, and Oman \\
\hline 6 & Federal Democracies (14) & $\begin{array}{l}\text { Argentina, Australia, Austria, Brazil, Canada, Colombia, Costa Rica, France, } \\
\text { India, Mexico, South Africa, United Kingdom, United States, and Venezuela. }\end{array}$ \\
\hline 7 & $\begin{array}{l}\text { Socialist/Communist } \\
\text { Countries (2) }\end{array}$ & Algeria and China \\
\hline
\end{tabular}

\section{Annexure 5: Countries covered in Regional groupings}

Botswana, Burundi, Cameroon, Congo DR, Congo R, Cote d'Ivoire, Egypt, Ethiopia

1 Africa (21) Gambia, Kenya, Lesotho, Madagascar, Morocco, Namibia, Rwanda, Sierra Leone, South Africa, Sudan, Tunisia, Uganda, and Zambia

2 Asia (19) Bhutan, China, India, Indonesia, Japan, Jordan, Kazakhstan, Korea R, Kyrgyz Republic,

2 Asia (19) Malaysia, Mauritius, Nepal, Oman, Pakistan, Singapore, Tajikistan, Thailand, and Turkey Albania, Algeria, Austria, Belgium, Bulgaria, Cyprus, Czech Republic, Denmark, Estonia,

3 Europe (34) Finland, France, Germany, Greece, Iceland, Ireland, Italy, Latvia, Lithuania, Luxembourg, Malta, Moldova, Netherlands, Norway, Poland, Portugal, Romania, Russian Federation, Slovak Republic, Slovenia, Spain, Sweden, Switzerland, Ukraine, and United Kingdom

$4 \begin{array}{ll}\text { North } \\ \text { America (07) }\end{array}$ Bahamas, Belize, Canada, Mexico, Panama, Trinidad and Tobago, and United States

5 Oceania (04) $\quad$ Australia, Fiji, New Zealand, and Papua New Guinea

6 South Chile, Colombia, Guatemala, Paraguay, Argentina, Brazil, Dominican Republic, Ecuador,

6 America (15) El Salvador, Peru, Uruguay, Bolivia, Costa Rica, Honduras, and Nicaragua 